Tarih Kültür ve Sanat Araştırmaları Dergisi

Revue des Recherches en Histoire Culture et Art

مجلة البحوث التاريخية و الثقافية والفنية
Vol. 7, No. 2, June 2018

Copyright (C) Karabuk University

http://kutaksam.karabuk.edu.tr

\title{
DOI: 10.7596/taksad.v7i2.1592
}

Citation: Kovaleva, V., Rusetskiy, M., Efremova, L., Kalakhanova, Z., \& Kochkarova, Z. (2018). Cultural and Historical Aspects in Developing the System of Accounting. Journal of History Culture and Art Research, 7(2), 4857. doi:http://dx.doi.org/10.7596/taksad.v7i2.1592

\section{Cultural and Historical Aspects in Developing the System of Accounting}

\author{
Valentina Danilovna Kovaleva1, Mikhail Gennad'evich Rusetskiy², \\ Lyudmila Anatolyevna Efremova3, Zukhra Mukhtarovna Kalakhanova4, \\ Zarema Ruslanovna Kochkarova ${ }^{5}$
}

\begin{abstract}
The article considers historical stages in the development of accounting as a part of the world culture. The specific features of each stage of evolution are represented and the main aspects of accounting information system as a source of relevant data are identified. The effectiveness of the controlling toolkit to improve the system of accounting is substantiated, the main provisions of the controlling conception are singled out and generalised; the scientific schools and their differences are identified. The analysis of various definitions revealing the content of the notion "culture" based on the condition and achievements of society as a collective of individuals who are in turn characterised by the unity of social, economic and cultural life is carried out. The essence of the notion "culture" and its versatility are determined; the actions of individuals responsible for the evolution of the economic life of society as a reaction to the obtained information are substantiated. The necessity to reflect the main provisions of accounting from the standpoint of their influence on economic decision-making, individuals' consciousness, distribution of resources, trajectory of economic development and the well-being of economic entity is investigated. The necessity to represent accounting as a subsystem of culture is substantiated. The main definitions of the notion "culture" which are most appropriate for characterising the subject matter of accounting are studied. The key aspects of describing the system of accounting as a culture component are identified.
\end{abstract}

Keywords: Culture, History, Accounting, Accountant, the system of accounting, Economy, Controlling, Conception, Period, Individual.

\footnotetext{
${ }^{1}$ Stavropol Institute of Cooperation (Branch) Belgorod University of Cooperation, Economics and Law (BUKEP) 36, Goleneva Street, Stavropol, Russia, 355000.

${ }^{2}$ North Caucasus Federal University (NCFU) 1, Pushkina Street, Stavropol, Russia, 355009.

${ }^{3}$ Kuban State Technological University (KubSTU) 2, Moskovskaya Street, Krasnodar, Russia, 350072.

${ }^{4}$ Stavropol Institute of Cooperation (Branch) Belgorod University of Cooperation, Economics and Law (BUKEP) 36, Goleneva Street, Stavropol, Russia, 355000.

${ }^{5}$ Stavropol Institute of Cooperation (Branch) Belgorod University of Cooperation, Economics and Law (BUKEP) 36, Goleneva Street, Stavropol, Russia, 355000.
} 


\section{Introduction}

Versatility that reflects diverse aspects of a historically determined level of social development can be considered as a distinctive feature of the notion "culture". It also includes creative potential and abilities of a person expressed in the types and forms of organising life and activity of humans, in their interrelations as well as in material and spiritual values created by them. Accounting representing the facts of economic activity throughout all the period of the development of mankind is also a component of culture. The essence of the system of accounting was fully manifested in the emblem of accountants designed by a French scientist Jean Baptiste Dumarchey (1874-1946) in 1944, it includes the following images:

- $\quad$ The Sun (accounting deals with economic activity);

- $\quad$ Scale (a symbol of balance);

- $\quad$ Bernoulli's spiral (a symbol of the fact that accounting will continue eternally once it started).

These symbols are determined by three mottos: science, conscience and independence (Economic Dictionary, 2018).

The symbols of the emblem of accountants reflect the significant role of accounting and accounting system in the development of the economy and world civilization in general. It is evident that the actions of individuals that determine the evolution of economic life of society are their reactions to particular information obtained. In this regard, the consideration of accounting as a part of the world culture contributes to representation of all the aspects of accounting information system as a source of relevant information.

\section{Methodology}

The methodological basis of the research consisted in the dialectical approach to the cognition of phenomena and patterns of development of accounting as a subsystem of culture aimed at improving the system of economic and business activity. The research is also based on the theory and methodology set forth in the fundamental works of Russian and foreign scientists on the problems of formation and development of accounting as an element of culture (Moles, 1973).

In our opinion that does not contradict the conception developed by a famous French physicist, philosopher and cultural scientist, Abraham Moles, culture includes the object results of human activity (machines, buildings, the results of cognition, works of art, moral norms and rights, etc.) as well as human forces and abilities implemented in activity (knowledge, skills, the level of intellect, moral and aesthetic development, worldview, means and forms of communication between people).

The use of theoretical approaches and economic integration conceptions in combination with the principles of social and cause-and-effect approaches enabled us to investigate the main stages of the development of accounting as a subsystem of culture at a sufficiently high scientific level.

The methodology of system analysis is implemented in the research, which included the use of a set of general scientific methods (system, complex, dialectic, induction and deduction, analysis and synthesis) as well as methods of morphological analysis (management by objectives), logical modelling.

\section{Results}

The main aspects reflecting the essence of the notion "culture" are disclosed, the role of culture in modern society is defined, the basis for its formation is determined and the possibility of this essential phenomenon 
to be an important component of the life of each individual is investigated. The essence of accounting as a subsystem of culture is revealed.

The results of the study are systematised in Table 1 that reflects the versatile nature of the term "culture" which is represented through a variety of definitions.

Table 1. Defining the term "culture"

\begin{tabular}{|c|c|c|}
\hline Author & Source & Definition \\
\hline $\begin{array}{l}\text { Ozhegov, S.I., } \\
\text { Shvedova, N.Yu. } \\
\text { (2008) }\end{array}$ & $\begin{array}{l}\text { Explanatory dictionary of } \\
\text { the Russian language }\end{array}$ & $\begin{array}{l}\text { A combination of productive, industrial, social and } \\
\text { spiritual, public achievements of mankind. }\end{array}$ \\
\hline Krysin, L.P. (2017) & $\begin{array}{l}\text { Explanatory dictionary of } \\
\text { foreign words }\end{array}$ & $\begin{array}{l}\text { A combination of achievements of humanity in } \\
\text { productive, social and intellectual aspects. }\end{array}$ \\
\hline $\begin{array}{l}\text { Yefremova, T.F. } \\
\text { (2000) }\end{array}$ & $\begin{array}{l}\text { The new dictionary of } \\
\text { the Russian language. } \\
\text { Explanatory-derivational. }\end{array}$ & $\begin{array}{l}\text { The level of the development of each sphere of life: } \\
\text { intellectual, social, productive. }\end{array}$ \\
\hline $\begin{array}{l}\text { Prokhorov, A.M. } \\
\text { (1993) }\end{array}$ & $\begin{array}{l}\text { Big encyclopedic } \\
\text { dictionary }\end{array}$ & $\begin{array}{l}\text { Culture (lat. cultura - cultivation, up-bringing, } \\
\text { education, development, reverence) is a historically } \\
\text { determined level of social development, creative } \\
\text { potential and abilities of a person manifested in the } \\
\text { types and forms of organising life and activity of } \\
\text { humans, in their interrelations as well as in material } \\
\text { and spiritual values created by them. } \\
\text { The notion "culture" is used to characterise particular } \\
\text { historical epochs (antique culture), particular } \\
\text { societies, peoples and nations (the Maya culture) as } \\
\text { well as specific spheres of life and activity (culture of } \\
\text { labour, political culture, artistic culture); in a narrower } \\
\text { sense-a sphere of spiritual life of people. } \\
\text { It comprises the object results of human activity } \\
\text { (machines, buildings, the results of cognition, works } \\
\text { of art, moral norms and rights, etc.) as well as human } \\
\text { forces and abilities implemented in activity } \\
\text { (knowledge, skills, the level of intellect, moral and } \\
\text { aesthetic development, worldview, means and forms } \\
\text { of communication between people). }\end{array}$ \\
\hline $\begin{array}{l}\text { Ushakov, D.N. } \\
\text { (2009) }\end{array}$ & $\begin{array}{l}\text { Big explanatory } \\
\text { dictionary of the modern } \\
\text { Russian language }\end{array}$ & $\begin{array}{l}\text { A combination of human achievements in subduing } \\
\text { the nature, in technology, education and social order. } \\
\text { This or that condition of social, economic, intellectual } \\
\text { life in a particular epoch with a particular people or } \\
\text { class. }\end{array}$ \\
\hline $\begin{array}{l}\text { Yevgenieva, A.P. } \\
\text { (1999) }\end{array}$ & $\begin{array}{l}\text { Small academic } \\
\text { dictionary of the Russian } \\
\text { language }\end{array}$ & $\begin{array}{l}\text { A combination of achievements of human society in } \\
\text { productive, social and spiritual life. }\end{array}$ \\
\hline
\end{tabular}

As a result of analysing different definitions characterising the notion "culture" it was determined that all of them are based on the condition and achievements of society, collective of people that are, in turn, 
characterised by the unity of social, economic and cultural life (Yefremova, 2000). In this connection, as we believe, a scientific work of a famous French physicist, philosopher and cultural scientist, Abraham Moles, "Social dynamics of culture" deserves special consideration. It is devoted to consideration of cultural aspects of mass communication; it was translated and published in the USSR and is based on the report "The dynamic philosophy and humanities". The author presented the results of a series of research and discussions conducted in 1958-1960 in the research centre of French radio and television for which he carried out the work to create the theory of means of culture distribution (Moles, 2005). Since the moment of it publishing in 1976 it has bees republished in the French language, translated into a number of other languages, thus, reviving the interest for the quantitative analysis of structural patterns of thinking. The influence of these patterns on everyday life and on the progress in the world of ideas constitutes the subject matter of this work that studies corresponding cyclical social processes.

In our opinion, the main conception of the given scientific work also deserved special attention. It presents ideas about socio-cultural cycle, a cyclical process of distributing ideas that is reinforced though the means of mass communication; due to that ideas gradually become commonly known and eventually serve as a material for further creativity. This conception received numerous experimental confirmations. As Abraham Moles believed, "Culture" is an exceptionally polysemantic term. Different authors understand it differently and there are more than 250 of its definitions. More than that, this word acquires various contents depending on time and place, on the character of society under study (Moles, 2005). According to the author, "From the pragmatic point of view, culture can be considered primarily as the intellectual "equipment" which every single person possesses at this or that moment as well as a structure of knowledge that he/she possesses as a member of any social group" (Moles, 2005).

In Table 1 we analysed five definitions of the notion "culture" which, in our opinion, are most appropriate for characterising the subject matter of accounting. In accordance with the versatility of the notion "culture" we suggest considering the system of accounting as a component of culture in two aspects:

1) as purely economic culture;

2) as common world culture in general.

The definition of culture systematised in Table 1 can be implemented to characterise the system of accounting. This can be accounted for by the essence of the notion "accounting" that reflects a part of people's activity which, in turn, inherently accompanies their economic life throughout thousands of years (Table 2).

Table 2. Main stages in the development of accounting

\begin{tabular}{|l|l|}
\hline $\begin{array}{l}\text { The first stage, } \\
\text { naturalistic (4000 BC-500 } \\
\text { BC) }\end{array}$ & $\begin{array}{l}\text { Accounting thought is primitive, an accountant presents in the reports what } \\
\text { he sees and with what he works. } \\
\text { The more precisely accounting records what happens in economy, the more } \\
\text { clear it becomes a fact economic life. } \\
\text { All the facts are divided into conditions that determined first accounting } \\
\text { means, inventory and collation, actions and events. } \\
\text { To record the facts of economic life first accounts emerged: inventory } \\
\text { (material) accounts, clearing accounts (current accounts). }\end{array}$ \\
\hline
\end{tabular}




\begin{tabular}{|c|c|}
\hline $\begin{array}{l}\text { The second stage, value } \\
\text { ( } 500 \mathrm{BC}-1300 \mathrm{AD})\end{array}$ & $\begin{array}{l}\text { The emergence of money led to a new means of assessment (first coins } \\
\text { appeared in } V \text { century } B C \text { ) that was carried out in all cases when money } \\
\text { serves as a means of assessing value. } \\
\text { Since that moment a fact of economic life was at first reflected in natural and } \\
\text { then in money measurement (or simultaneously). } \\
\text { With the emergence of money accounting was to be divided into patrimonial } \\
\text { one (patrimonia means possession, property) when money act as a measure } \\
\text { of value and cameral - as a means of payment (Azriliyan, 1999). }\end{array}$ \\
\hline $\begin{array}{l}\text { The third stage, } \\
\text { digraphic (1300-1850) }\end{array}$ & $\begin{array}{l}\text { To identify the financial result of economic activity patrimonial accounting } \\
\text { had to be divided into unigraphic } \\
\text { (simple record) and digraphic (double record) (Azriliyan, 1999). } \\
\text { In terms of accounts there appeared escrows (accounts of order and } \\
\text { method) and accounts of one's own funds (capital account, profit and loss } \\
\text { accounts). }\end{array}$ \\
\hline $\begin{array}{l}\text { The fourth stage, } \\
\text { theoretical-practical } \\
(1850-1900)\end{array}$ & $\begin{array}{l}\text { In this period digraphic accounting developed in two directions: from the } \\
\text { standpoint of jurisprudence and economics. } \\
\text { The desire to know the content of accounted processes led to the emergence } \\
\text { of balance, profit, cost price, production and circulation costs. } \\
\text { Conditional accounts appeared (income and expenditure accounts, contra } \\
\text { accounts) }\end{array}$ \\
\hline $\begin{array}{l}\text { The fifth stage, scientific } \\
(1900-1950)\end{array}$ & $\begin{array}{l}\text { In the mid-XIX century the bases of accounting science were laid. To the end } \\
\text { of the XIX century the legal interpretation of accounting was predominant; } \\
\text { since the XX century its economic understanding gained acknowledgement. } \\
\text { The accounting of expenditures and calculation of cost price of work and } \\
\text { services became of considerable importance at this stage. } \\
\text { In regard to expenditure accounts patrimonial and cameral accounting were } \\
\text { connected. } \\
\text { The theory of cost calculation was originated in the XX century. } \\
\text { The influence of cameral accounting created the systems of standard-costing } \\
\text { (preliminary calculation and strict setting of forthcoming expenditures) and } \\
\text { direct-costing (a method that includes only fixed expenditures into cost } \\
\text { price). } \\
\text { At the beginning of 1950-s a method of accounting expenditures by centres } \\
\text { of responsibility appeared that is accounting of costs by place of fixation. }\end{array}$ \\
\hline $\begin{array}{l}\text { The sixth stage, modern } \\
\text { (since 1950) }\end{array}$ & $\begin{array}{l}\text { The dynamic and static understanding of balance developed. } \\
\text { The dynamic understanding and methods of calculation resulted in the } \\
\text { appearance of management accounting. }\end{array}$ \\
\hline
\end{tabular}




\begin{tabular}{|l|l|}
\hline & $\begin{array}{l}\text { The static understanding determined the emergence of International } \\
\text { Accounting Standards (IAS) (Kovaleva, 2018). } \\
\text { Both these approaches led to the formation of tax accounting and affected } \\
\text { it as well. } \\
\text { Every account becomes a "black box" that has an entrance (debit) and exit } \\
\text { (credit). } \\
\text { Accounting is carried out on behalf of various groups. } \\
\text { a) Tax accounting on behalf of the state. } \\
\text { b) Financial accounting on behalf of the proprietor. } \\
\text { c) Management accounting on behalf of administration. } \\
\text { d) Accounting in the interests of all the above-mentioned. }\end{array}$ \\
\hline
\end{tabular}

As a result of the analysis of the data presented in Table 2 it was determined that the development of accounting is based on the development of accounting thought; the essence of its evolution consists in the transition from a concrete understanding of economy to a more abstract one, thus, contributing to improving the processes of managing economic activity.

In this regard, to ensure effective monitoring it is necessary to improve the very instrument of managing the accounting methodology which has gone through the main stages multiplying, becoming more complex and improving on the basis of modern innovative controlling technology. Controlling provides a methodical and instrumental base to support the basic management functions: planning, monitoring, accounting, analysis and assessing the situation for management decision-making (Kovaleva, 2005).

Having analysed the concept "controlling" from the standpoint of various scientific schools we found out that presently two models are implemented: American and German ones. The main difference between them consists in the level of decision-making. The German model focuses on the tasks of internal accounting, whereas the American model encompasses the tasks of managing finances and information technologies as well.

Basing on the analysis of scientific views of Russian and foreign authors we singled out six conceptions reflecting main provisions of controlling (Table 3).

Table 3. Main provisions of the conceptions of controlling

\begin{tabular}{|c|c|c|}
\hline Years & Name of the conception of controlling & Authors and supporters \\
\hline $80-s$ & Management accounting & $\begin{array}{l}\text { Mann, R., Mayer, E., Vollmuth, H., Deyhle, A., } \\
\text { Glushchenko, V.V., Glushchenko, I.I. }\end{array}$ \\
\hline Late 80 -s & Management information system & $\begin{array}{c}\text { Reichmann, T., Preißler, P., Berr, H., } \\
\text { Brüggemeier, M. }\end{array}$ \\
\hline Early 90-s & Planning and controlling & Hahn, D., Horváth, P., Schneider, D. \\
\hline
\end{tabular}




\begin{tabular}{|c|c|c|}
\hline 90-s & Coordination & Küpper, H., Schmidt, A., Weber, J., Zünd, A. \\
\hline Late 90-s & Meta-system of management & $\begin{array}{c}\text { Steinmann, H., Newman, W., Zürz, I., Ananyina, E.A., } \\
\text { Danilochkina, N.G., Karminsky, A.M., Olenev, N.I., } \\
\text { Primak, A.G. }\end{array}$ \\
\hline $2000-\mathrm{s}$ & $\begin{array}{c}\text { Coordination of the decision-making } \\
\text { process }\end{array}$ & $\begin{array}{c}\text { Pich, G., Sherm, E., Steinmann, H., Sroman, G., Sydow, } \\
\text { J., Windeler, A., Giddens, A., Becker, A. }\end{array}$ \\
\hline
\end{tabular}

The data presented in Table 3 demonstrate that the assessment of the role and place of controlling in management sufficiently ranges from performing main functions of management (planning, organising, controlling, regulating, analysing) to reducing to functions of planning and controlling or coordinating the system of management (Kovaleva, 2005). We found out that the trajectory of the development of controlling as well as the trajectory of the development of accounting follows the growth pattern, its subject matter, research object, methods and models are specified. In this regard, accounting can be considered as an element of culture since it is a combination of humanity achievements in the field of methods of presenting data on economic activity.

\section{Discussion}

The opinion that we share that accounting can be considered as an element of culture does not contradict the conception of Abraham Moles, according to which the understanding of accounting as an element of culture corresponds to the understanding of this phenomena that existed form the late XVIII century until recently. According to a French physicist, philosopher and cultural scientist, Abraham Moles, "The notion of culture was created about two centuries ago by philosophers. The term "culture" can be found in a German dictionary published in 1793 . However, as the author claims, until quite recently sociology contributed to enriching culture mainly by creating new facts of culture but not by developing theories on it. The success achieved up to the present moment by sciences implementing statistical methods on the background of current quantitative growth of culture facts on the one hand and the development of theory and practice of modelling on the other hand evidently provide grounds for making a new attempt to design a doctrine about culture" (Moles, 1973).

We found out that accounting is one of multiple of directions of knowledge constituting economic science which can be referred to social sciences. In this regard, sociological research in the field of economics is necessary for its development and sociology is one of the crucial bases for understanding modern economy in general and accounting in particular.

We believe that the conception of Abraham Moles reflecting main aspects of culture is relevant for accounting as well since the theory of accounting is devoted to presenting the facts of accounting, thus, revealing internal aspects of accounting: the description of methods of accounting, mechanisms of their application, information about authors who characterise these methods and complement them with their own ideas. It is evident that these reasoning remain within the limits of accounting proper without enabling to disclose accounting from the outside. In this regard, the analysis of accounting statements is considered as something independent compared to accounting which to unjustified distinction between two categories of specialists:

- $\quad$ In the field of accounting and generating statements; 
- $\quad$ In the field of financial analysis.

However, claiming that accounting and its methods are related to science we should take into account the fact that "science deals with measurements and forms. Its progress is based on continuous alternate identifying of facts by means of measuring and creating conceptions that make up "forms". Influencing the field of phenomena... a researcher interprets them in an abstract language of symbols with the help of a glossary of universal terms" (Moles, 1973).

Consequently, accounting could be a truthful science about enterprise if managers of companies talked to each other using a language of accounting when discussing decisions to be made. Presently, as A. Moles notes, "the place of classical humanities is more often occupied by the so-called sciences of humans the object of which is a doer" (Moles, 1973). These sciences include disciplines not connected with the biology cycle such as psychology, sociology and practical ethics. In this regard, when studying accounting it is necessary to cognise a person since accounting statements is an informational message addressed to unlimited (financial statements) and limited (management reports) groups of people (Provisions on accounting (PA), 4/99).

Each message consists of particular data reflecting the results of company's activity that is characterised by the given statements which include assets, profits and income, accounts payable, etc. The people who use these statements can constitute certain interest groups including creditors, proprietors, investors, purchasers, employers, general public, fiscal bodies, etc. (Federal law, №402). The list of such groups of users and the characteristics of their informational needs are revealed in International Financial Reporting Standards (IFRS) (International Standards of Financial Reporting and Their Explanations, 2018).

However, these abstract groups of users of accounting data always comprise real individuals and their acquaintance with the data of statements occurs in accordance with all the laws and patterns of information perception. The reaction to the corresponding data is determined by the way they are perceived; this reaction reflects the economic decisions that determine certain actions to distribute economic resources. These are people who react to information, make decisions and act; these are theirs behavioural reactions to accounting statements and deeds in social environment. In this regard, all socio-cultural aspects of peoples' lives are directly related to accounting as well.

All economic behaviour of people is determined by the general patterns and laws of its commitment to taking pleasure and avoiding suffering. According to S. Freud, "We do not hesitate to accept a provision that the flow of mental processes is automatically regulated by the principle of pleasure. Each time it arises, connects itself to the tension of displeasure and follows the direction that eventually coincides with decreasing this tension, in other words, with diminishing displeasure and taking pleasure" (Freud, 1991). The author believes that pleasure consists in increasing wealth or the feeling of wealth to be more precise, whereas displeasure (suffering) is connected with the loss of wealth or the feeling of this loss to be more exact.

Obviously, the increase in wealth in the modern world is associated with the concept of profit, whereas the loss of wealth is connected with material losses. Demonstrating profits and losses accounting stimulates financial statements users' mental processes connected with taking pleasure or suffering. The desire to take pleasure stimulates the purchase of shares of profitable companies and the achievement of high profitability of their activity. The supply of inheritable information influences the associations connected with pleasure or suffering of specific individuals. It is accounted for by the fact that in the cultural (suprabiological) layer of human existence as a social unit social heredity is active. It is based on the patterns and laws of perception of the inherited history of social environment in which an individual is born and lives obtaining individual history. Individual history reflects the acquired education and personal experience of 
economic activity with the use of the data of accounting. The influence of the surrounding environment to which an individual reacts at the present moment is based on the obtained and analysed data of accounting.

Thus, to present accounting as a part of culture is to make an attempt to understand how and why an individual and society in general react to the obtained accounting data. If a user of accounting statements can notice that, according to accounting balance data, a company shows an increase in turnover of assets and at the same time accounts payable do not grow, assets are perceived as meeting (covering) liabilities (Sokolov, 2003). Consequently, if assets grow, it indicates solvency and creditworthiness and can cause a reaction such as credit provision for this firm (Savitskaya, 2013).

However, the growth of current assets can be caused exclusively by the changes of the methods of accounting envisaged by the accounting policy of a company (Provisions on accounting (PA), 1/2008). FIFO (first in, first out) method is chosen, semi-fixed cost is included into production cost, more depreciation is charged due to revaluation of non-current assets in particular, heavy expensed are shown as future period expenses, the evaluation of current assets is higher which is not connected with the growth of settling debts but can be perceived exactly this way (Horngren \& Foster, 2000).

In this regard, in the process of the analysis of accounting methods of presenting economic facts and approaches to forming accounting statements it is necessary to pay attention to the compliance of these methods and approaches with the provisions of economic science and law as well as to the patterns of individual perception of accounting data by individuals making economic decisions basing on them.

\section{Conclusion}

The results of the conducted analysis enabled to find out that the notion "culture" is characterised by versatility that reflects various aspects that in turn reflect a historically determined level of social development; these aspects are relevant for accounting as well. It is accounted for by the fact that the theory of accounting is based on presenting facts of economic activity; it reveals internal aspects of the system of accounting and describes the methods and mechanisms of their application. Throughout the whole period of the development the system of accounting, acting as one of the main elements of culture, plays an important role in the development of economy and the world civilization in general.

The development of accounting is based on the evolution of accounting thought contributing to improving the processes of managing economic activity in terms of improving the methodology on the grounds of controlling.

The essence of accounting as a subsystem of culture is revealed through studying the significance of this phenomenon for the life of every individual.

The consideration of accounting as a part of culture is based on the reaction of an individual and society in general to the obtained accounting data. In this regard, the consideration of accounting as a part of the world culture contributes to the reflection of all aspects of accounting information system as a source of relevant information.

\section{Conflict of interest}

The authors confirm that the data do not contain any conflict of interest. 


\section{References}

Azriliyan, A. N. (ed.) (1999). Big accounting dictionary. Moscow: Institute of New Economics.

Economic Dictionary (2018). Available at: http://www.moneyball.info/61866-gerb-bukhgalterovjekonomicheskijj-slovar.html

Federal law №402-FL "On accounting". (Edition of 2018). Available at: http://ipipip.ru/zakon-o-buhuchete/ Freud, S. (1991). Introduction to psychoanalysis. Moscow: Azbuka.

Horngren, C. \& Foster, G. (2000). Cost Accounting: A Managerial Emphasis. Moscow: Finances and Statistics. International standards of financial reporting and their explanations (2018). Available at: http://www.consultant.ru/document/cons_doc_LAW_140000/

Kovaleva, V. D. (2005). Financial controlling in entrepreneur activity. Starvtopol: Servisshkola.

Kovaleva, V. D. (2018). International standards of accounting and financial reporting. Moscow: Publishing House "Sputnik+".

Krysin, L. P. (2017). Explanatory dictionary of foreign words. Moscow: AST-PRESS.

Moles, A. (1973). Sociodynamics of culture. Moscow: Progress.

Moles, A. (2005). Sociodynamics of culture. Moscow: Komkniga.

Ozhegov, S. I. (2008). Explanatory dictionary of the Russian language. Moscow: Oniks.

Prokhorov, A. M. (1993). Big encyclopedic dictionary. Moscow: Sovetskaya Entsiklopediya.

Provisions on accounting (PA) 1/2008. "Accounting policy of a company". (Approved by order № 106n of the Ministry of Finance of the Russian Federation on 6 October 2008 (Edition of 18 December 2012)).

Provisions on accounting (PA) 4/99. "Accounting statements of a company".

Savitskaya, G. V. (2013). The analysis of economic activity of a company. Moscow: Infra-M.

Sokolov, Ya. V. (2003). The basics of accounting theory. Moscow: Finances and Statistics.

Ushakov, D. N. (2009). Big explanatory dictionary of the modern Russian language. Moscow: AST.

Yefremova, T. F. (2000). The new dictionary of the Russian language. Explanatory-derivational. Moscow: Russky yazyk.

Yevgenieva, A. P. (1999). Small academic dictionary of the Russian language. Moscow: RAS, Institute of Linguistic Research. 